\title{
Preventive and therapeutic challenges in combating Zika virus infection: are we getting any closer?
}

\author{
Meera V. Singh ${ }^{1}$ • Emily A. Weber ${ }^{1}$ - Vir B. Singh ${ }^{1}$ • Nicole E. Stirpe ${ }^{1}$ • \\ Sanjay B. Maggirwar ${ }^{1}$
}

Received: 23 November 2016/Accepted: 10 January 2017 / Published online: 23 January 2017

(C) The Author(s) 2017. This article is published with open access at Springerlink.com

\begin{abstract}
The neuroteratogenic nature of Zika Virus (ZIKV) infection has converted what would have been a tropical disease into a global threat. Zika is transmitted vertically via infected placental cells especially in the first and second trimesters. In the developing central nervous system (CNS), ZIKV can infect and induce apoptosis of neural progenitor cells subsequently causing microcephaly as well as other neuronal complications in infants. Its ability to infect multiple cell types (placental, dermal, and neural) and increased environmental stability as compared to other flaviviruses (FVs) has broadened the transmission routes for ZIKV infection from vector-mediated to transmitted via body fluids. To further complicate the matters, it is genetically similar (about 40\%) with the four serotypes of dengue virus (DENV), so much so that it can almost be called a fifth DENV serotype. This homology poses the risk of causing cross-reactive immune responses and subsequent antibody-dependent enhancement (ADE) of infection in case of secondary infections or for immunized individuals. All of these factors complicate the development of a single preventive vaccine candidate or a pharmacological intervention that will completely eliminate or cure ZIKV infection. We discuss all of these factors in detail in this review and conclude that a combinatorial approach including immunization and treatment might prove to be the winning strategy.
\end{abstract}

Meera V. Singh

meera_singh@urmc.rochester.edu

1 Department of Microbiology and Immunology, University of Rochester School of Medicine and Dentistry, 601 Elmwood Avenue, Rochester, NY 14642, USA
Keywords Zika virus · Microcephaly $\cdot$ Antibody dependent enhancement of infection · Therapeutics

\section{Background}

Multiple reports have now confirmed that Zika virus (ZIKV) is a neuroteratogenic pathogen and is the causative agent of microcephaly and other developmental anomalies of the central nervous system (CNS) in children born to infected mothers (Cugola et al. 2016; Franca et al. 2016; Li et al. 2016a; Miner et al. 2016; Pacheco et al. 2016; Roberts and Frosch 2016). Not only that, but it is also associated with Guillain-Barre syndrome (GBS) (Araujo et al. 2016; CaoLormeau et al. 2016; Roze et al. 2016), thrombocytopenia (Karimi et al. 2016; Sharp et al. 2016), and ocular complications (Moshfeghi et al. 2016; Parke et al. 2016; Valentine et al. 2016; Ventura et al. 2016) in infected individuals. It is a mosquito-borne flavivirus (FV) that was isolated in 1947 from a rhesus monkey in the Zika forest of Uganda (Dick 1952; Dick et al. 1952) and has caused major epidemics in Micronesia, French Polynesia, and South and Central America since 2007 (Weaver et al. 2016; White et al. 2016). The severity of the current epidemic has prompted massive research effort to understand and eradicate this global health concern.

Lot of meaningful data has been generated in a very short time covering different aspects of the infection, from its association with microcephaly to mechanistic insights into neuropathogenesis as well as placental transmission; however, we are yet to come up with an efficient strategy to tackle this eminent threat. The purpose of this review is to examine the factors that, we deem, play a very decisive role in designing preventive and therapeutic measures to combat ZIKV infection. 


\section{Environmental stability and cellular tropism of ZIKV}

While most of the FVs are mainly transmitted through vector bite (except for hepatitis $\mathrm{C}$ virus, which is a non-arboviral FV) (Blitvich and Firth 2015), ZIKV has been shown to be transmitted sexually as well as vertically. It can persist in semen for longer time (Harrower et al. 2016; Mansuy et al. 2016; Matheron et al. 2016; Reusken et al. 2016; Turmel et al. 2016) and was also detected in breast milk (DupontRouzeyrol et al. 2016), saliva, and urine (Bonaldo et al. 2016; Fourcade et al. 2016; Liuzzi et al. 2016; Wiwanitkit 2016). Further, it was found to retain most of its infectivity during a $\mathrm{pH}$ range of 5-11 (Muller et al. 2016), is much more stable at higher temperatures as compared to other FVs, and can remain infectious for up to 3 days in the form of dried spots (Kostyuchenko et al. 2016; Muller et al. 2016). Investigators led by Kostuchenko speculated that ZIKV expands into smooth-surfaced particles when incubated in harsher conditions making the lipid envelope more fluid and then allowing it to revert back to its normal state. They attributed this to a one-residue insertion (Ala340) in the DIII domain of E protein, which helps in forming an extra hydrogen bond with other interacting DIII domains of nearby E proteins (Kostyuchenko et al. 2016). These are important factors to be kept in consideration while developing preventive/therapeutic approaches against ZIKV.

Further, ZIKV also has a very broad tropism and is known to use Axl, Tim1, Tyro3, and DC-SIGN as entry receptors in different cell types. ZIKV was shown to infect and replicate in human dermal fibroblasts, epidermal keratinocytes, and immature dendritic cells in vitro (Hamel et al. 2015). Miner and colleagues found virus in the placental trophoblasts of mice infected with Zika (Miner et al. 2016). Additionally, Zika virus has been found to replicate in several human trophoblast cell lines, but not trophoblast cells from full term placentas that release type II IFN (Bayer et al. 2016; El Costa et al. 2016; Miner et al. 2016). Tabata et al. infected different primary cell types from mid- and late-gestation placentas and explants from first-trimester chorionic villi. They found that ZIKV-infected cytotrophoblasts, endothelial cells, fibroblasts, and Hofbauer cells in chorionic villi and amniotic epithelial cells and trophoblast progenitors in amniochorionic membranes. Furthermore, it infected these cells with higher viral titers in mid gestation versus late gestation (Tabata et al. 2016). Further, multiple studies have indicated that ZIKV infects neural stem cell progenitors, radial glia, as well as astrocytes (Brault et al. 2016; Cugola et al. 2016; Dang et al. 2016; Garcez et al. 2016; Hughes et al. 2016; Li et al. 2016b; Nowakowski et al. 2016; Tang et al. 2016). This data suggests that ZIKV can infect the fetus through placental transmission early in gestation by infecting multiple placental cell types in the first or second trimesters. Once inside the developing fetus, ZIKV targets neural progenitor cells and hinders their differentiation and subsequently causes microcephaly (Cugola et al. 2016; Dang et al. 2016; Garcez et al. 2016; Hughes et al. 2016; Li et al. 2016a; Tang et al. 2016).

\section{Zika-associated microcephaly and other cortical malformations}

FVs can be broadly categorized into two types based on their pathogenic effects as hemorrhagic viruses, such as dengue virus (DENV), yellow fever virus (YFV), and encephalitic viruses, like West Nile virus (WNV), Japanese encephalitis virus (JEV), and now ZIKV. Other than prenatal death (van der Eijk et al. 2016), microcephaly is by far the most severe and irreversible complication associated with ZIKV infection. It results in a cerebral cortex that is reduced in size, whereas overall organization of the brain is mostly unaffected. However, some cases are also known to be associated with abnormal gyral pattern (microlissencephaly, i.e., smooth agyrus brain) and other brain malformations (Gilmore and Walsh 2013; Mlakar et al. 2016; Strafela et al. 2016).

A recent ZIKV outbreak in northeast Brazil was associated with a rise in infants born with microcephaly (Schuler-Faccini et al. 2016). Another study examining the physiology of neonates and fetuses from ZIKV positive pregnant women found incedences of microcephaly, cerebral calcifications, and intrauterine growth restriction (Brasil et al. 2016). In some cases, ZIKV infection was also linked to early fetal death (Brasil et al. 2016; Franca et al. 2016; Meaney-Delman et al. 2016). In yet another report, close examination of 1501 suspected cases of congenital Zika virus syndrome found that $83 \%$ of definite or probable cases could be identified by microcephaly (Franca et al. 2016). More recently, data from the epidemiological reports of Health Surveillance (Brazilian Ministry of Health) indicates that of the 1656 confirmed cases of microcephaly or other neurological abnormalities, $15.4 \%$ were associated with ZIKV infection (Magalhaes-Barbosa et al. 2016). This causal link between the increase of microcephaly along with other fetal impairments and ZIKV infection in pregnant women has been strengthened by virologic evidence. Researchers in French Polynesia reviewed stored samples of amniotic fluid from cases with fetal cerebral anomaly and microcephaly to discover that four out of five specimens were found positive for ZIKV (Besnard et al. 2016). Similarly, amniotic fluid from two pregnant women in Brazil whose fetuses had microcephaly tested positive for ZIKV (Calvet et al. 2016). Additional studies have found the presence of ZIKV directly in the microcephalic fetal brain tissues (Driggers et al. 2016; Mlakar et al. 2016; Sarno et al. 2016; Schuler-Faccini et al. 2016). Several murine models have provided crucial evidence confirming the relationship between ZIKV and fetal microcephaly. Studies in which 
pregnant SJL mice were given a ZIKV strain isolated from northeast Brazil resulted in progeny's brain tissue containing viral RNA and microcephaly-associated malformations, such as reduced cell numbers and cortical layer thickness (Cugola et al. 2016). Similar defects were observed in pups following ZIKV infection of pregnant mice that lacks type I interferon signaling (A129 mice) (Li et al. 2016a; Miner et al. 2016). All of these reports conclusively establish ZIKV as a causative agent for microcephaly.

Due to the lack of systematic documentation or scarcity of longitudinally collected clinical specimen, it remains unclear if ZIKV infection during specific trimester serves as a risk factor. However, a strong association between fetal microcephaly and infection in the first trimester or early in the second trimester has been determined based on data collected from both Brazil and French Polynesia (Cauchemez et al. 2016; Franca et al. 2016; Johansson et al. 2016; Reefhuis et al. 2016; Schuler-Faccini et al. 2016). Additional data recently collected from a study in Colombia suggests that infection in the third trimester is not closely linked with any defects in the fetus (Pacheco et al. 2016). This trend in infection timing and outcome is similar to other pathogens that infect the fetus such as, Rubella, cytomegalovirus (CMV), and Toxoplasma gondii (Jenum et al. 1998; Mathur et al. 1982; Miller et al. 1982; Pass et al. 2006). However, there is still a concern that ZIKV could be dangerous for fetuses even in the third trimester. Reports have shown that abnormal fetus outcomes with infections up to 36 weeks of gestation (Brasil et al. 2016; Soares de Souza et al. 2016).

Despite the strong evidence that shows association of fetal neuronal defects with ZIKV infection, the molecular pathways involved in ZIKV-associated microcephaly are largely unknown except for two recent reports. First, an excellent study by Liang et al. showed that ZIKV NS4A and NS4B proteins induce autophagy in human fetal NSCs by deregulating AktmTOR signaling (Liang et al. 2016b), whereas Dang et al. showed that ZIKV depletes neural progenitors through activation of Toll-like receptor 3 (TLR3) (Dang et al. 2016). In addition, much can be learned from what is known about microcephaly vera (true microcephaly), an autosomal recessive neurodevelopmental defect. There are multiple genes associated with microcephaly vera, including MCPH1, ASPM, CDK5RAP2, CENPJ, STIL, WDR62, CEP135, CEP152, CEP63, and CEP152, all of which encode for proteins associated with centrosome, mitotic spindles, or centrioles (David et al. 2014; Gilmore and Walsh 2013). During neurogenesis, the fate of dividing neuronal precursors is very critical in defining the ultimate size of the cortex. Nearly all neurons in the cerebral cortex complete proliferation by mid-gestation, and none are generated after birth (Spalding et al. 2005). Further in more complex vertebrate CNS, the newly specified neurons migrate to a specific location before they differentiate and form synapses (Cooper 2013). Hence, it has been proposed that microcephaly is caused by reduced number of neurons owing to defective mitoses of fetal neuronal precursor cells as well as impaired migration of the neurons to designated areas of the brain.

$\mathrm{Li}$ and coworkers found decreased expression of most of the above-mentioned genes in microcephalic progeny of IFNRI/II knockout mice infected with ZIKV ( $\mathrm{Li}$ et al. 2016a). Further, in vitro studies have demonstrated that ZIKV induces cell death in human induced pluripotent stem cell (iPS)-derived neural stem cells and disrupts the formation of neurospheres and reduces the growth of brain organoids (Cugola et al. 2016; Dang et al. 2016; Garcez et al. 2016). Hughes et al. infected various neuroblastoma cell lines at different stages of differentiation with PRVABC strain of ZIKV and showed that only the undifferentiated cells were permissive to infection (Hughes et al. 2016). Brault et al. demonstrated that ZIKV and WNV both showed neurotropism in in vitro infection experiments; however, only ZIKV impaired cell cycle progression of neural stem cells (Brault et al. 2016). All of these findings together indicate that ZIKV infection has a teratogenic window, mostly occurring in the first trimester, while the neuronal stem cells are still differentiating. During this time period, maternal infection can lead to microcephaly by targeting cortical progenitor cells, inducing cell death as well as impaired neuronal migration.

\section{Other ZIKV-associated health sequelae}

Another negative neurological association of ZIKV infection is the occurrence of GBS (Araujo et al. 2016; Cao-Lormeau et al. 2016; Dos Santos et al. 2016; Roze et al. 2016). It is an acute, immune-mediated polyradiculoneuropathy typically occurring after a range of infections including upper respiratory infections, like influenza, and digestive tract infections, notably Campylobacter jejuni and CMV or Epstein-Barr virus infections (Araujo et al. 2016; Cao-Lormeau et al. 2016; Roze et al. 2016). It is not clear what causes the onset of GBS; however, different mechanisms including molecular mimicry, epitope spreading, bystander activation, and production of superantigens have been proposed (Anaya et al. 2016). In axonal variants of GBS, the presence of a broad range of anti-glycolipid IgG antibodies directed to gangliosides has been described (Rinaldi and Willison 2008; Willison 2007). Interestingly, Cao-Lormeau and colleagues found that 41 of the 42 individuals diagnosed with GBS during the ZIKV epidemic in 2013-2014 in French Polynesia had anti-ZIKV virus IgM or IgG and had experienced a transient illness in a median of 6 days before the onset of neurological symptoms, suggesting a recent ZIKV infection (Cao-Lormeau et al. 2016). All of these individuals were seronegative for any other infections known to be associated with GBS. However, they found a less than $50 \%$ occurrence of the anti-glycolipid antibodies in these 
individuals suggesting that ZIKV-associated GBS pathogenesis might involve other mechanisms in addition to autoimmune response against glycolipids/gangliosides.

In addition to neurologic complications, ZIKV infection might be associated with hematologic abnormalities as well. So far, there have been three reported cases (in two independent studies) of ZIKV-associated severe thrombocytopenia and subcutaneous hematomas (Karimi et al. 2016; Sharp et al. 2016). Thrombocytopenia is also associated with DENV infection (de Azeredo et al. 2015). Studies have reported increased thrombopoietin (TPO) levels in the blood of DENV-infected individuals (Matondang et al. 2004), and that DENV inhibits TPO-inducible megakaryocyte differentiation from CD34+ cord blood cells in vitro (Basu et al. 2008; Murgue et al. 1997; Nakao et al. 1989). Some reports also indicate increased clearance of circulating platelets either by platelet consumption due to coagulopathy or via activation of the complement system or by formation of anti-platelet antibodies by molecular mimicry (Alonzo et al. 2012; Honda et al. 2009; Lin et al. 2001; Lin et al. 2011; Srichaikul et al. 1989). It is probable that DENVassociated thromobocytopenia occurs due to both decreased production of cells from bone marrow and an increased peripheral destruction of platelets. Further research is warranted to assess if ZIKV uses mechanisms similar to DENV to induce thrombocytopenia.

In addition, there are multiple reports of ocular complications such as unilateral acute maculopathy, pigmentory retinopathy, and atrophy in infants with ZIKV infection (Parke et al. 2016). Macular and chorioretinal disease can significantly impact visual development in infant (Moshfeghi et al. 2016; Valentine et al. 2016; Ventura et al. 2016). Lastly, reports suggest an association between ZIKV infection and hearing loss. Leal et al. reported that prevalence of ZIKV-associated sensorineural hearing loss was 5.8\%, similar to hearing loss associated with other congenital viral infections (Leal et al. 2016). Interestingly, Vinhaes et al. identified three cases of transient hearing loss in ZIKV-infected (Vinhaes et al, 2016). However, it is not yet clear if these complications are directly caused by ZIKV or are secondary to microcephaly. Nonetheless, in addition to brain malformations, all of these probable ZIKV-related health complications pose a serious concern and will affect the prognosis for ZIKV infection.

\section{Immune response against $\mathrm{ZIKV}$ infection}

While there is a definite association between ZIKV infection and microcephaly, not all infants born to infected mothers have these complications, indicating that robust maternal immune responses might be able to protect the fetus from detrimental effects of ZIKV infection in some cases. Insights into ZIKV pathogenesis and immune correlates of protection can be gleaned from the prevailing mouse models as well as lessons learned from studies with other FVs. In vitro infection of fibroblasts causes an increase of antiviral pattern recognition receptors, such as TLR3 at an early stage and later RIG-I and MDA5 , leading to an induction of interferon alpha and interferon beta (Hamel et al. 2015). Mouse models have also been utilized to show the important immune cell types in ZIKV defense. Immunocompetent C57/BL6 and CD1 mice show no illness upon infection with ZIKV, whereas A129 mice and AG129 (IFN type I and II receptor knock out) mice developed signs of illness like hunched posture and ruffled fur, and the fetuses from infected mothers showed microcephaly (Rossi et al. 2016). It is worth noting that the mortality due to ZIKV infection in these experimental groups was not uniform, as few A129 mice with ZIKV died within 6 days, while other A129 infected mice survived the infection. Similar findings have also been reported with respect to DENV infection, where the innate immune response, especially type I and type II IFNs are postulated to orchestrate the disease outcome (Clyde et al. 2006; Rodenhuis-Zybert et al. 2010). Inoculation with the yellow fever YF-17D vaccine can delay the onset of dengue fever upon subsequent infection with DENV within a short window of vaccination (Liang et al. 2016a), further emphasizing the crucial role of innate immune response in defense against ZIKV.

SJL mice have also been used as a model for ZIKV infection. These mice exhibit normal IFN responses however show delayed B cell responses and lack natural killer cells (Hutchings et al. 1986; Sellers et al. 2012). Even though the fetuses from ZIKV-infected SJL dams did not develop microcephaly, they had cortical malformations, indicative of microcephaly (Cugola et al. 2016). This data points towards the requirement of NK cell-mediated immunity and neutralizing antibody response to combat ZIKV infection. A study with YF vaccine, YF17D, further confirms the importance of NK cell-mediated immune responses in anti-FV immunity wherein the authors showed that IFN- $\gamma+$ NK cells and IL- $4+$ NK cells were significantly increased along with multiple NK-associated genes after the administration of this vaccine to healthy individuals (Gaucher et al. 2008; Silva et al. 2011). Another recent paper showed that $\mathrm{T}$ lymphocytes were not as important as neutralizing antibody response in ZIKV immunity (Larocca et al. 2016). In this study, the investigators produced a DNA vaccine expressing fulllength ZIKV pre-membrane and envelope proteins and reported that a single injection with this vaccine provided complete protection against ZIKV infection in Balb/C and SJL mice upon viral challenge. Adoptive transfer of purified IgG from immunized mice conferred passive protection, while depletion of CD4 and CD8 T lymphocytes in vaccinated mice did not affect protective efficacy of the vaccine, indicating that ZIKV envelope-specific antibody response might be the correlate of immune protection. This finding was further supported by one more report, in which the researchers developed a panel of antiZIKV monoclonal antibodies by inoculating irf $^{-/}$mice with live virus followed by boost with either the virus or E proteins. 
They found that the antibodies against the DIII domain of E protein not only possessed neutralizing activity but also protected IFN-deficient mice from lethal infection (Zhao et al. 2016). Overall, these studies highlight the role for innate and antibody-mediated immune responses in anti-ZIKV immunity, and a candidate vaccine that will stimulate these types of immune responses might be highly desirable.

\section{Current anti-ZIKV vaccine efforts and comparison with other $F V$ vaccines}

The use of vaccines to prevent viral infections is the most costeffective public healthy strategy, and vaccines are currently in use for other FVs, including YF, JEV, and tick-borne encephalitis viruses (TBEV) (Ishikawa et al. 2014). The YF-17D vaccine for yellow fever is one of the most successful anti-FV vaccines and an excellent roadmap for generalization of immune correlates of protection against FVs (Pulendran 2009; Pulendran et al. 2013). The rubella pandemic from 1962 to 1965 caused congenital rubella syndrome, including fetal impairments like deafness and developmental delays, in 20,000 infants in the USA. Since the development and implementation of the rubella vaccine, these numbers have fallen to less than ten cases per year (MartinezPalomo 2016). Preliminary work using a guinea pig model for CMV, which causes mental retardation and deafness in infants, showed that vaccination was able to reduce transmission and mortality in pups caused by CMV infection (Choi et al. 2016). In 2015, the first vaccine for prevention of DENV, Dengvaxia, was licensed for persons aged 9-45 years living in DENV endemic regions. It is a chimeric yellow fever-DENV tetravalent live-attenuated vaccine and is estimated to reduce disease burden by $10-30 \%$ over a period of 30 years. It is also associated with high risk of hospitalization for children under 9 years of age. Further, Dengvaxia seems more effective against secondary DENV infection and has lower efficacy when given to denguenaïve people (WHO 2016b). A successful vaccine candidate might be expected to provide similar relief from negative congenital effects associated with ZIKV infection during pregnancy.

Current anti-ZIKV vaccine strategies utilize diverse range of molecular approaches. In March 2016, the World Health Organization compiled a list of 18 active programs (including 5 academic and 15 commercial groups) pursuing different strategies in parallel. Approaches used include live-attenuated virus, nucleic acid based, live vectors, subunit vaccines, and nanoparticles (WHO 2016a). In June 2016, Inovio Pharmaceuticals announced that they have received approval to initiate phase I human trial to evaluate the DNA vaccine (GLS-5700) produced by Larocca et al. (Larocca et al. 2016; Morrison 2016). Further, Sapparapu et al. isolated broadly neutralizing anti-ZIKV antibodies from infected individuals and showed that preimmunization with these antibodies, significantly reduced placental transmission of ZIKV in mouse models (Sapparapu et al. 2016).
However, while animal and small sample trials for these and other candidate vaccines might be completed very soon, longterm efficacy trials and approval are likely to take years. At the same time, the possibility of causing antibody-dependent enhancement (ADE) of DENV infection by ZIKV vaccine and vice versa will also impact the development of a successful vaccine.

\section{Antibody-dependent enhancement of infection: potential roadblock in development of ZIKV prophylaxis}

The recently licensed DENV vaccine is partially successful and can be used only in a certain population (aged 9-45 years) living in highly endemic areas (WHO 2016b). Unlike YF and JEV vaccines, the development of a successful DENV vaccine has proven challenging due to the existence of four divergent serotypes of DENV. Epidemiological evidence suggests that primary infection confers protection against reinfection with the same serotype but can cause severe disease upon reinfection with a different serotype, owing to ADE. ADE occurs when antibodies generated during primary infection fail to neutralize the virus of a different serotype during secondary infection, instead causing enhanced infectivity of target cells through virus opsonization and Fc-receptor-mediated endocytosis (Halstead 2014). Phylogenetic analyses of human pathogenic FVs using RNA polymerase NS5 indicate that ZIKV clusters with the encephalitic viruses; however, when the $\mathrm{E}$ protein sequence is considered, it branches with DENV group (Barba-Spaeth et al. 2016). The four DENV serotypes differ from each other by $30-35 \%$, and this serocomplex in turn is different from ZIKV by $41-46 \%$ (Dejnirattisai et al. 2016; Screaton et al. 2015). This difference indicates that vaccine design against ZIKV infection might not be as straight forward as with YF or JEV. Multiple recent reports confirm that this divergence in structure is not just a theoretical obstacle but is causing actual issues in vaccine development.

Barba-Spaeth and coworkers identified structural details of a quaternary epitope in DENV known as envelope dimer epitope (EDE) formed at the interface of two enveloped monomers, 90 of which are arranged in icosahedral symmetry into the DENV glycoprotein shell. Antibodies targeting this region can be divided into two categories: EDE1, which is not sensitive to glycosylation at the Asn153 residue and EDE2, which requires the $\mathrm{N}$-linked glycan at Asn153. They found that antibodies targeting EDE1, especially C8 and C10, efficiently neutralized ZIKV, while other antibodies targeting the fusion loop epitope were just cross-reactive (Barba-Spaeth et al. 2016). A study by Dejnirattisai et al. showed that multiple anti-DENV antibodies not only fail to neutralize the infection but also cause ADE (Dejnirattisai et al. 2016). In this study, preincubation of ZIKV with anti-dengue immune sera or well-characterized anti-dengue monoclonal antibodies (including EDE1 C8 and C10) lead to increased infection of U937 monocytic cells with ZIKV. 
However, for unknown reasons, the combination of both these immune components was able to neutralize ZIKV.

Swanstrom et al. confirmed the neutralizing potential of these two antibodies in human monocytic cell line, U937-DC-SIGN, and Vero cells (Swanstrom et al. 2016). In addition, IFN-type I/II receptor knockout mice, when pretreated with $\mathrm{C} 10$ antibody, exhibited no signs of illness upon infection with ZIKV. They also found that antibodies, which are capable of neutralizing only one or two DENV serotypes, failed to neutralize ZIKV. Further, in the same study, sera obtained from DENV-infected individuals (with one or more than one serotypes) several years postinfection, failed to cross-neutralize ZIKV. Similar results were noted by Priyamvada and her team in which they tested acute and convalescent sera from patients with DENV infection and showed that while some anti-DENV antibodies confer neutralization of ZIKV infection, most antibodies caused ADE (Priyamvada et al. 2016). In yet another study by Stettler et al., 119 antiZIKV monoclonal antibodies were isolated from two ZIKV-infected, DENV-naïve individuals and two ZIKV-infected, DENVimmune donors and compared with a panel of $\mathrm{mAbs}$ previously isolated from ZIKV-naïve, DENV-infected donors. Of the 119 antibodies, 41 were against NS1 and the rest were against $\mathrm{E}$ protein. Of the NS1 antibodies, only the ones from ZIKV-infected, DENV-immune individuals were cross-reactive, while antibodies from ZIKV-infected, DENV-naïve, and DENV-infected, ZIKV-naïve individuals were reactive only to antigens from specific viruses. Interestingly, the anti-E antibodies from ZIKV-infected, DENV-naïve individuals cross-reacted with $\mathrm{E}$ protein of the four DENV serotypes and vice versa. They also found that cross-reactive antibodies elicited by either viruses and primarily directed to EDI/II domains could mediate heterologous ADE, while antibodies against EDIII and quaternary epitopes present on infectious virus cause potent neutralization (Stettler et al. 2016). While contradictory in some aspects, all of these reports elucidate that antibodies against different serotypes of DENV and ZIKV are definitely cross-reactive. These studies reveal the complexity of a potential antibody-based vaccine for ZIKV, especially as both of these viruses are prevalent in the same geographical areas. This also means that it might be necessary to explore the potential of therapeutic drugs for treatment of ZIKV infection.

\section{Pharmacological interventions against ZIKV infection}

Prevention of mother to fetus transmission via the use of an entry inhibitor would be the ideal solution to avoid cortical complications in the infants. Recent reports suggest that Axl is the primary entry receptor used by ZIKV in neuronal as well as skin cells (Hamel et al. 2015; Nowakowski et al. 2016), while placental cells exhibit consistently high levels of TIM1 receptor and that is utilized by ZIKV to infect these cells (Tabata et al. 2016). Similar results were also obtained by
Sapparapu et al. via injection of broadly neutralizing antiZIKV antibodies from infected humans into pregnant mice (Sapparapu et al. 2016). Further, Tabata et al. were able to significantly reduce the ZIKV infection of early and midgestation placental explants by using Duramycin, an inhibitor of TIM1 receptor, while the Axl inhibitor R428 had a modest effect. Duramycin is also known to inhibit infection by DENV, WNV, and Ebola virus (Richard et al. 2015), indicating that use of entry inhibitors might prove be an effective strategy to prevent transplacental transmission of ZIKV. Using a different approach, Barrows et al. screened a library of FDA-approved drugs for their ability to block in vitro infection of $\mathrm{HuH}-7$ cell line by ZIKV and found 20 plausible candidates (Barrows et al. 2016). Some of these candidates were further validated for inhibition of ZIKV infection in human cervical, neural, and placental cells. The candidate compounds include few previously known anti-flaviviral drugs like bortezomib, while some were newly identified to have antiviral activity like daptomycin and sertraline. On similar lines, $\mathrm{Xu}$ et al. designed a compound screening approach using caspase-3 activity as the primary screening assay and confirmed the neuroprotective nature of the identified compounds by a secondary cell viability assay. This lead to identification of two types of drugs, antiviral, and neuroprotective. Emricasan, a pan-caspase inhibitor, was identified as the most efficient prosurvival compound, while niclosamide and PHA-690509 were found to have potent antiviral activity. Interestingly, a combination of the two types of drugs helped the infected neural progenitor cells recover by preventing their apoptosis (Xu et al. 2016).

Repurposing of FDA-approved drugs to identify anti-ZIKV compounds is an advantageous strategy that has proven successful in case of other infections such as Ebola and hepatitis C virus (He et al. 2015; Johansen et al. 2015) and especially required in case of ZIKV infection because there are no approved anti-flavivirus treatments and development of an efficacious vaccine will take a long time. Combining antiviral compounds with a neuroprotective drug might also prove extremely beneficial, but with a caution, that use of a pan-caspase inhibitor might have detrimental side effects on brain development. Induction of apoptosis is necessary during neurodevelopment to prevent brain overgrowth as well as establishment of appropriate neuronal connectivity and synapse formation (Yamaguchi and Miura 2015). Instead, pharmacological agents that activate signaling pathways involved in neurodevelopment and survival of neuronal progenitors, such as sonic hedgehog (Shh) signaling, might prove an interesting avenue of pursuit. This signaling pathway is crucial for maintenance of neural progenitor pool in fetal and adult brains (Machold et al. 2003). Further, our group has shown the neuroprotective effects of Shh pathway augmentation via a small molecule, smoothened agonist (SAG), against human immunodeficiency virus (HIV)-associated neuropathology in humanized mice (Singh et al. 2016). Not only that, but SAG was also shown to prevent 
neuropathology in a rat model of spinal cord injury as well as a mouse model for Down's syndrome(Bambakidis et al. 2010; Bragina et al. 2010), indicating that this approach might lead to timely identification of a neuroprotective drug in order to dampen ZIKV-associated neurological complications.

\section{Concluding remarks}

ZIKV infection is spreading across the globe at an alarming pace not only in vector-prevalent areas but also to other countries like USA, because of a wider range of routes of transmission. What started as yet another tropical disease has ended up being a much more serious threat because of its association with neurologic complications. Based on our knowledge so far, an ideal ZIKV prophylactic or therapeutic agent will be required to satisfy various criteria such as,

1. Prevent ADE for ZIKV infection in DENV-immune individuals and vice versa.

2. Not increase the chances of developing/worsening GBS, which means that the use of live-attenuated vaccines may be ruled out until the cause of GBS is identified.

3. Safe for use in pregnant population and immunecompromised individuals especially because persons with immunosuppression or autoimmune disorders are at a higher risk of developing severe disease (Azevedo et al. 2016).

4. Keep in consideration the broader tropism as well as increased stability of the ZIKV and its effect on the different modes of transmission.

While development of a preventive vaccine candidate is extremely important, it is also necessary to focus attention on identifying pharmacological agents that can either prevent/reduce mother to infant transmission or confer neuroprotection in the presence of viral burden. Considering these multiple factors, it seems likely that a combination of these two approaches will be the most successful in eradicating this global threat.

Acknowledgements We would like to thank Dr. Joseph Jackson and Ryan Connor for their valuable comments during manuscript revisions. This work was supported by the National Institute of Health (NIH) grants RO1 NS054578, RO1 NS066801, and RO1 HL1281555 to SBM.

\section{Compliance with ethical standards}

Conflict of interest The authors declare that they have no conflict of interest.

Open Access This article is distributed under the terms of the Creative Commons Attribution 4.0 International License (http://creativecommons.org/ licenses/by/4.0/), which permits unrestricted use, distribution, and reproduction in any medium, provided you give appropriate credit to the original author(s) and the source, provide a link to the Creative Commons license, and indicate if changes were made.

\section{References}

Alonzo MT, Lacuesta TL, Dimaano EM, Kurosu T, Suarez LA, Mapua CA, Akeda Y, Matias RR, Kuter DJ, Nagata S, Natividad FF, Oishi K (2012) Platelet apoptosis and apoptotic platelet clearance by macrophages in secondary dengue virus infections. The Journal of Infectious Diseases 205:1321-1329

Anaya JM, Ramirez-Santana C, Salgado-Castaneda I, Chang C, Ansari A, Gershwin ME (2016) Zika virus and neurologic autoimmunity: the putative role of gangliosides. BMC Medicine 14:49

Araujo LM, Ferreira ML, Nascimento OJ (2016) Guillain-Barre syndrome associated with the Zika virus outbreak in Brazil. Arq Neuropsiquiatr 74:253-255

Azevedo RS, Araujo MT, Martins Filho AJ, Oliveira CS, Nunes BT, Cruz AC, Nascimento AG, Medeiros RC, Caldas CA, Araujo FC, Quaresma JA, Vasconcelos BC, Queiroz MG, da Rosa ES, Henriques DF, Silva EV, Chiang JO, Martins LC, Medeiros DB, Lima JA, Nunes MR, Cardoso JF, Silva SP, Shi PY, Tesh RB, Rodrigues SG, Vasconcelos PF (2016) Zika virus epidemic in Brazil. I. Fatal disease in adults: clinical and laboratorial aspects. J Clin Virol 85:56-64

Bambakidis NC, Wang X, Lukas RJ, Spetzler RF, Sonntag VK, Preul MC (2010) Intravenous hedgehog agonist induces proliferation of neural and oligodendrocyte precursors in rodent spinal cord injury. Neurosurgery 67:1709-1715 discussion 1715

Barba-Spaeth G, Dejnirattisai W, Rouvinski A, Vaney MC, Medits I, Sharma A, Simon-Loriere E, Sakuntabhai A, Cao-Lormeau VM, Haouz A, England P, Stiasny K, Mongkolsapaya J, Heinz FX, Screaton GR, Rey FA (2016). Structural basis of potent Zikadengue virus antibody cross-neutralization. Nature.

Barrows NJ, Campos RK, Powell ST, Prasanth KR, Schott-Lerner G, Soto-Acosta R, Galarza-Munoz G, McGrath EL, Urrabaz-Garza R, Gao J, Wu P, Menon R, Saade G, Fernandez-Salas I, Rossi SL, Vasilakis N, Routh A, Bradrick SS, Garcia-Blanco MA (2016). A screen of FDA-approved drugs for inhibitors of Zika virus infection. Cell host \& microbe.

Basu A, Jain P, Gangodkar SV, Shetty S, Ghosh K (2008) Dengue 2 virus inhibits in vitro megakaryocytic colony formation and induces apoptosis in thrombopoietin-inducible megakaryocytic differentiation from cord blood CD34+ cells. FEMS Immunol Med Microbiol 53: 46-51

Bayer A, Lennemann NJ, Ouyang Y, Bramley JC, Morosky S, Marques ET Jr, Cherry S, Sadovsky Y, Coyne CB (2016) Type III interferons produced by human placental trophoblasts confer protection against Zika virus infection. Cell Host Microbe 19:705-712

Besnard M, Eyrolle-Guignot D, Guillemette-Artur P, Lastere S, BostBezeaud F, Marcelis L, Abadie V, Garel C, Moutard ML, Jouannic JM, Rozenberg F, Leparc-Goffart I, Mallet HP (2016). Congenital cerebral malformations and dysfunction in fetuses and newborns following the 2013 to 2014 Zika virus epidemic in French Polynesia. Euro surveillance: bulletin Europeen sur les maladies transmissibles = European communicable disease bulletin 21 .

Blitvich BJ, Firth AE (2015) Insect-specific flaviviruses: a systematic review of their discovery, host range, mode of transmission, superinfection exclusion potential and genomic organization. Viruses 7 : 1927-1959

Bonaldo MC, Ribeiro IP, Lima NS, Dos Santos AA, Menezes LS, da Cruz SO, de Mello IS, Furtado ND, de Moura EE, Damasceno L, da Silva KA, de Castro MG, Gerber AL, de Almeida LG, Lourenco- 
de-Oliveira R, Vasconcelos AT, Brasil P (2016) Isolation of infective Zika virus from urine and saliva of patients in Brazil. PLoS Negl Trop Dis 10:e0004816

Bragina O, Sergejeva S, Serg M, Zarkovsky T, Maloverjan A, Kogerman P, Zarkovsky A (2010) Smoothened agonist augments proliferation and survival of neural cells. Neurosci Lett 482:81-85

Brasil P, Pereira JP, Jr., Raja Gabaglia C, Damasceno L, Wakimoto M, Ribeiro Nogueira RM, Carvalho de Sequeira P, Machado Siqueira A, Abreu de Carvalho LM, Cotrim da Cunha D, Calvet GA, Neves ES, Moreira ME, Rodrigues Baiao AE, Nassar de Carvalho PR, Janzen C, Valderramos SG, Cherry JD, Bispo de Filippis AM, Nielsen-Saines K (2016). Zika virus infection in pregnant women in Rio de Janeiro - preliminary report. The New England journal of medicine.

Brault JB, Khou C, Basset J, Coquand L, Fraisier V, Frenkiel MP, Goud B, Manuguerra JC, Pardigon N, Baffet AD (2016). Comparative analysis between flaviviruses reveals specific neural stem cell tropism for Zika virus in the mouse developing neocortex. EBioMedicine.

Calvet G, Aguiar RS, Melo AS, Sampaio SA, de Filippis I, Fabri A, Araujo ES, de Sequeira PC, de Mendonca MC, de Oliveira L, Tschoeke DA, Schrago CG, Thompson FL, Brasil P, Dos Santos FB, Nogueira RM, Tanuri A, de Filippis AM (2016) Detection and sequencing of Zika virus from amniotic fluid of fetuses with microcephaly in Brazil: a case study. Lancet Infect Dis 16:653-660

Cao-Lormeau VM, Blake A, Mons S, Lastere S, Roche C, Vanhomwegen J, Dub T, Baudouin L, Teissier A, Larre P, Vial AL, Decam C, Choumet V, Halstead SK, Willison HJ, Musset L, Manuguerra JC, Despres P, Fournier E, Mallet HP, Musso D, Fontanet A, Neil J, Ghawche F (2016) Guillain-Barre syndrome outbreak associated with Zika virus infection in French Polynesia: a case-control study. Lancet 387:1531-1539

Cauchemez S, Besnard M, Bompard P, Dub T, Guillemette-Artur P, Eyrolle-Guignot D, Salje H, Van Kerkhove MD, Abadie V, Garel C, Fontanet A, Mallet HP (2016) Association between Zika virus and microcephaly in French Polynesia, 2013-15: a retrospective study. Lancet 387:2125-2132

Choi KY, Root M, McGregor A (2016). A novel non-replication competent cytomegalovirus capsid mutant vaccine strategy is effective in reducing congenital infection. Journal of virology.

Clyde K, Kyle JL, Harris E (2006) Recent advances in deciphering viral and host determinants of dengue virus replication and pathogenesis. J Virol 80:11418-11431

Cooper JA (2013) Cell biology in neuroscience: mechanisms of cell migration in the nervous system. J Cell Biol 202:725-734

Cugola FR, Fernandes IR, Russo FB, Freitas BC, Dias JL, Guimaraes KP, Benazzato C, Almeida N, Pignatari GC, Romero S, Polonio CM, Cunha I, Freitas CL, Brandao WN, Rossato C, Andrade DG, Faria Dde P, Garcez AT, Buchpigel CA, Braconi CT, Mendes E, Sall AA, Zanotto PM, Peron JP, Muotri AR, Beltrao-Braga PC (2016) The Brazilian Zika virus strain causes birth defects in experimental models. Nature 534:267-271

de Azeredo EL, Monteiro RQ, de Oliveira Pinto LM (2015) Thrombocytopenia in dengue: interrelationship between virus and the imbalance between coagulation and fibrinolysis and inflammatory mediators. Mediat Inflamm 2015:313842

Dang J, Tiwari SK, Lichinchi G, Qin Y, Patil VS, Eroshkin AM, Rana TM (2016). Zika virus depletes neural progenitors in human cerebral organoids through activation of the innate immune receptor TLR3. Cell stem cell.

David A, Liu F, Tibelius A, Vulprecht J, Wald D, Rothermel U, Ohana R, Seitel A, Metzger J, Ashery-Padan R, Meinzer HP, Grone HJ, Izraeli S, Kramer A (2014) Lack of centrioles and primary cilia in STIL(-/-) mouse embryos. Cell Cycle 13:2859-2868

Dejnirattisai W, Supasa P, Wongwiwat W, Rouvinski A, Barba-Spaeth G, Duangchinda T, Sakuntabhai A, Cao-Lormeau VM, Malasit P, Rey
FA, Mongkolsapaya J, Screaton GR (2016). Dengue virus serocross-reactivity drives antibody-dependent enhancement of infection with zika virus. Nature immunology.

Dick GW (1952) Zika virus. II. Pathogenicity and physical properties. Trans R Soc Trop Med Hyg 46:521-534

Dick GW, Kitchen SF, Haddow AJ (1952) Zika virus. I. Isolations and serological specificity. Trans R Soc Trop Med Hyg 46:509-520

Dos Santos T, Rodriguez A, Almiron M, Sanhueza A, Ramon P, de Oliveira WK, Coelho GE, Badaro R, Cortez J, Ospina M, Pimentel R, Masis R, Hernandez F, Lara B, Montoya R, Jubithana B, Melchor A, Alvarez A, Aldighieri S, Dye C, Espinal MA (2016) Zika virus and the Guillain-Barre syndrome - case series from seven countries. N Engl J Med 375:1598-1601

Driggers RW, Ho CY, Korhonen EM, Kuivanen S, Jaaskelainen AJ, Smura T, Rosenberg A, Hill DA, DeBiasi RL, Vezina G, Timofeev J, Rodriguez FJ, Levanov L, Razak J, Iyengar P, Hennenfent A, Kennedy R, Lanciotti R, du Plessis A, Vapalahti O (2016) Zika virus infection with prolonged maternal viremia and fetal brain abnormalities. N Engl J Med 374:2142-2151

Dupont-Rouzeyrol M, Biron A, O'Connor O, Huguon E, Descloux E (2016) Infectious Zika viral particles in breastmilk. Lancet 387:1051

El Costa H, Gouilly J, Mansuy JM, Chen Q, Levy C, Cartron G, Veas F, Al-Daccak R, Izopet J, Jabrane-Ferrat N (2016) ZIKA virus reveals broad tissue and cell tropism during the first trimester of pregnancy. Sci Rep 6:35296

Fourcade C, Mansuy JM, Dutertre M, Delpech M, Marchou B, Delobel P, Izopet J, Martin-Blondel G (2016) Viral load kinetics of Zika virus in plasma, urine and saliva in a couple returning from Martinique, French West Indies. Journal of clinical virology : the official publication of the Pan American Society for Clinical Virology 82:1-4

Franca GV, Schuler-Faccini L, Oliveira WK, Henriques CM, Carmo EH, Pedi VD, Nunes ML, Castro MC, Serruya S, Silveira MF, Barros FC, Victora CG (2016). Congenital Zika virus syndrome in Brazil: a case series of the first 1501 livebirths with complete investigation. Lancet.

Garcez PP, Loiola EC, Madeiro da Costa R, Higa LM, Trindade P, Delvecchio R, Nascimento JM, Brindeiro R, Tanuri A, Rehen SK (2016) Zika virus impairs growth in human neurospheres and brain organoids. Science 352:816-818

Gaucher D, Therrien R, Kettaf N, Angermann BR, Boucher G, FilaliMouhim A, Moser JM, Mehta RS, Drake DR 3rd, Castro E, Akondy R, Rinfret A, Yassine-Diab B, Said EA, Chouikh Y, Cameron MJ, Clum R, Kelvin D, Somogyi R, Greller LD, Balderas RS, Wilkinson P, Pantaleo G, Tartaglia J, Haddad EK, Sekaly RP (2008) Yellow fever vaccine induces integrated multilineage and polyfunctional immune responses. J Exp Med 205:3119-3131

Gilmore EC, Walsh CA (2013) Genetic causes of microcephaly and lessons for neuronal development. Wiley Interdisciplinary Reviews Developmental Biology 2:461-478

Halstead SB (2014) Dengue antibody-dependent enhancement: knowns and unknowns. Microbiology Spectrum 2

Hamel R, Dejarnac O, Wichit S, Ekchariyawat P, Neyret A, Luplertlop N, Perera-Lecoin M, Surasombatpattana P, Talignani L, Thomas F, Cao-Lormeau VM, Choumet V, Briant L, Despres P, Amara A, Yssel H, Misse D (2015) Biology of Zika virus infection in human skin cells. J Virol 89:8880-8896

Harrower J, Kiedrzynski T, Baker S, Upton A, Rahnama F, Sherwood J, Huang QS, Todd A, Pulford D (2016) Sexual transmission of Zika virus and persistence in semen, New Zealand, 2016. Emerg Infect Dis 22

He S, Lin B, Chu V, Hu Z, Hu X, Xiao J, Wang AQ, Schweitzer CJ, Li Q, Imamura M, Hiraga N, Southall N, Ferrer M, Zheng W, Chayama K, Marugan JJ, Liang TJ (2015) Repurposing of the antihistamine chlorcyclizine and related compounds for treatment of hepatitis $\mathrm{C}$ virus infection. Sci Transl Med 7:282ra49 
Honda S, Saito M, Dimaano EM, Morales PA, Alonzo MT, Suarez LA, Koike N, Inoue S, Kumatori A, Matias RR, Natividad FF, Oishi K (2009) Increased phagocytosis of platelets from patients with secondary dengue virus infection by human macrophages. AmJTrop Med Hyg 80:841-845

Hughes BW, Addanki KC, Sriskanda AN, McLean E, Bagasra O (2016). Infectivity of immature neurons to Zika virus: a link to congenital Zika syndrome. EBioMedicine.

Hutchings PR, Varey AM, Cooke A (1986) Immunological defects in SJL mice. Immunology 59:445-450

Ishikawa T, Yamanaka A, Konishi E (2014) A review of successful flavivirus vaccines and the problems with those flaviviruses for which vaccines are not yet available. Vaccine 32:1326-1337

Jenum PA, Stray-Pedersen B, Melby KK, Kapperud G, Whitelaw A, Eskild A, Eng J (1998) Incidence of toxoplasma gondii infection in 35,940 pregnant women in Norway and pregnancy outcome for infected women. J Clin Microbiol 36:2900-2906

Johansen LM, DeWald LE, Shoemaker CJ, Hoffstrom BG, Lear-Rooney CM, Stossel A, Nelson E, Delos SE, Simmons JA, Grenier JM, Pierce LT, Pajouhesh H, Lehar J, Hensley LE, Glass PJ, White JM, Olinger GG (2015) A screen of approved drugs and molecular probes identifies therapeutics with anti-Ebola virus activity. Sci Transl Med 7:290ra89

Johansson MA, Mier-y-Teran-Romero L, Reefhuis J, Gilboa SM, Hills SL (2016) Zika and the risk of microcephaly. N Engl J Med 375:1-4

Karimi O, Goorhuis A, Schinkel J, Codrington J, Vreden SG, Vermaat JS, Stijnis C, Grobusch MP (2016) Thrombocytopenia and subcutaneous bleedings in a patient with Zika virus infection. Lancet 387:939 940

Kostyuchenko VA, Lim EX, Zhang S, Fibriansah G, Ng TS, Ooi JS, Shi J, Lok SM (2016) Structure of the thermally stable Zika virus. Nature 533:425-428

Larocca RA, Abbink P, Peron JP, Zanotto PM, Iampietro MJ, BadamchiZadeh A, Boyd M, Ng'ang'a D, Kirilova M, Nityanandam R, Mercado NB, Li Z, Moseley ET, Bricault CA, Borducchi EN, Giglio PB, Jetton D, Neubauer G, Nkolola JP, Maxfield LF, Barrera RA, Jarman RG, Eckels KH, Michael NL, Thomas SJ, Barouch DH (2016). Vaccine protection against Zika virus from Brazil. Nature.

Leal MC, Muniz LF, Ferreira TS, Santos CM, Almeida LC, Van Der Linden V, Ramos RC, Rodrigues LC, Neto SS (2016). Hearing Loss in Infants with Microcephaly and Evidence of Congenital Zika Virus Infection - Brazil, November 2015-May 2016. MMWR Morb Mortal Wkly Rep 65:917-9.

Li C, Xu D, Ye Q, Hong S, Jiang Y, Liu X, Zhang N, Shi L, Qin CF, Xu Z (2016a) Zika virus disrupts neural progenitor development and leads to microcephaly in mice. Cell Stem Cell 19:120-126

Li H, Saucedo-Cuevas L, Regla-Nava JA, Chai G, Sheets N, Tang W, Terskikh AV, Shresta S, Gleeson JG (2016b) Zika virus infects neural progenitors in the adult mouse brain and alters proliferation. Cell Stem Cell 19:593-598

Liang H, Lee M, Jin X (2016a) Guiding dengue vaccine development using knowledge gained from the success of the yellow fever vaccine. Cellular \& molecular Immunology 13:36-46

Liang Q, Luo Z, Zeng J, Chen W, Foo SS, Lee SA, Ge J, Wang S, Goldman SA, Zlokovic BV, Zhao Z, Jung JU (2016b) Zika virus NS4A and NS4B proteins deregulate Akt-mTOR signaling in human fetal neural stem cells to inhibit neurogenesis and induce autophagy. Cell Stem Cell 19:663-671

Lin CF, Lei HY, Liu CC, Liu HS, Yeh TM, Wang ST, Yang TI, Sheu FC, Kuo CF, Lin YS (2001) Generation of IgM anti-platelet autoantibody in dengue patients. J Med Virol 63:143-149

Lin YS, Yeh TM, Lin CF, Wan SW, Chuang YC, Hsu TK, Liu HS, Liu CC, Anderson R, Lei HY (2011) Molecular mimicry between virus and host and its implications for dengue disease pathogenesis. Exp Biol Med 236:515-523
Liuzzi G, Nicastri E, Puro V, Zumla A, Ippolito G (2016). Zika virus in saliva - new challenges for prevention of human to human transmission. European journal of internal medicine.

Machold R, Hayashi S, Rutlin M, Muzumdar MD, Nery S, Corbin JG, Gritli-Linde A, Dellovade T, Porter JA, Rubin LL, Dudek H, McMahon AP, Fishell G (2003) Sonic hedgehog is required for progenitor cell maintenance in telencephalic stem cell niches. Neuron 39:937-950

Magalhaes-Barbosa MC, Prata-Barbosa A, Robaina JR, Raymundo CE, Lima-Setta F, Cunha AJ (2016) Trends of the microcephaly and Zika virus outbreak in Brazil, January-July 2016. Travel Med Infect Dis $14: 458-463$

Mansuy JM, Pasquier C, Daudin M, Chapuy-Regaud S, Moinard N, Chevreau C, Izopet J, Mengelle C, Bujan L (2016) Zika virus in semen of a patient returning from a non-epidemic area. Lancet Infect Dis 16:894-895

Martinez-Palomo A (2016). Revisiting Zika (and Rubella). Journal of public health policy.

Matheron S, D’Ortenzio E, Leparc-Goffart I, Hubert B, de Lamballerie X, Yazdanpanah Y (2016). Long lasting persistence of Zika virus in semen. Clinical infectious diseases: an official publication of the Infectious Diseases Society of America.

Mathur A, Arora KL, Chaturvedi UC (1982) Transplacental Japanese encephalitis virus (JEV) infection in mice during consecutive pregnancies. The Journal of general virology 59:213-217

Matondang AV, Widodo D, Zulkarnain I, Rengganis I, Trihandini I, Inada K, Endo S (2004) The correlation between thrombopoietin and platelet count in adult dengue viral infection patients. Acta medica Indonesiana 36:62-69

Meaney-Delman D, Hills SL, Williams C, Galang RR, Iyengar P, Hennenfent AK, Rabe IB, Panella A, Oduyebo T, Honein MA, Zaki S, Lindsey N, Lehman JA, Kwit N, Bertolli J, Ellington S, Igbinosa I, Minta AA, Petersen EE, Mead P, Rasmussen SA, Jamieson DJ (2016) Zika virus infection among U.S. pregnant travelers-August 2015-February 2016. MMWR Morb Mortal Wkly Rep 65:211-214

Miller E, Cradock-Watson JE, Pollock TM (1982) Consequences of confirmed maternal rubella at successive stages of pregnancy. Lancet 2: $781-784$

Miner JJ, Cao B, Govero J, Smith AM, Fernandez E, Cabrera OH, Garber C, Noll M, Klein RS, Noguchi KK, Mysorekar IU, Diamond MS (2016) Zika virus infection during pregnancy in mice causes placental damage and fetal demise. Cell 165:1081-1091

Mlakar J, Korva M, Tul N, Popovic M, Poljsak-Prijatelj M, Mraz J, Kolenc M, Resman Rus K, Vesnaver Vipotnik T, Fabjan Vodusek V, Vizjak A, Pizem J, Petrovec M, Avsic Zupanc T (2016) Zika virus associated with microcephaly. N Engl J Med 374:951-958

Morrison C (2016) DNA vaccines against Zika virus speed into clinical trials. Nat Rev Drug Discov 15:521-522

Moshfeghi DM, de Miranda HA, 2nd, Costa MC (2016). Zika virus, microcephaly, and ocular findings. JAMA ophthalmology.

Muller JA, Harms M, Schubert A, Jansen S, Michel D, Mertens T, Schmidt-Chanasit J, Munch J (2016) Inactivation and environmental stability of Zika virus. Emerg Infect Dis 22

Murgue B, Cassar O, Guigon M, Chungue E (1997) Dengue virus inhibits human hematopoietic progenitor growth in vitro. The Journal of infectious diseases 175:1497-1501

Nakao S, Lai CJ, Young NS (1989) Dengue virus, a flavivirus, propagates in human bone marrow progenitors and hematopoietic cell lines. Blood 74:1235-1240

Nowakowski TJ, Pollen AA, Di Lullo E, Sandoval-Espinosa C, Bershteyn M, Kriegstein AR (2016) Expression analysis highlights $\mathrm{AXL}$ as a candidate Zika virus entry receptor in neural stem cells. Cell Stem Cell 18:591-596

Pacheco O, Beltran M, Nelson CA, Valencia D, Tolosa N, Farr SL, Padilla AV, Tong VT, Cuevas EL, Espinosa-Bode A, Pardo L, 
Rico A, Reefhuis J, Gonzalez M, Mercado M, Chaparro P, Martinez Duran M, Rao CY, Munoz MM, Powers AM, Cuellar C, Helfand R, Huguett C, Jamieson DJ, Honein MA, Ospina Martinez ML (2016). Zika virus disease in Colombia-preliminary report. The New England journal of medicine.

Parke DW, 3rd, Almeida DR, Albini TA, Ventura CV, Berrocal AM, Mittra RA (2016). Serologically confirmed Zika-related unilateral acute maculopathy in an adult. Ophthalmology.

Pass RF, Fowler KB, Boppana SB, Britt WJ, Stagno S (2006) Congenital cytomegalovirus infection following first trimester maternal infection: symptoms at birth and outcome. Journal of clinical virology: the official publication of the Pan American Society for Clinical Virology 35:216-220

Priyamvada L, Quicke KM, Hudson WH, Onlamoon N, Sewatanon J, Edupuganti S, Pattanapanyasat K, Chokephaibulkit K, Mulligan MJ, Wilson PC, Ahmed R, Suthar MS, Wrammert J (2016) Human antibody responses after dengue virus infection are highly cross-reactive to Zika virus. Proc Natl Acad Sci U S A 113:78527857

Pulendran B (2009) Learning immunology from the yellow fever vaccine: innate immunity to systems vaccinology. Nat Rev Immunol 9: 741-747

Pulendran B, Oh JZ, Nakaya HI, Ravindran R, Kazmin DA (2013) Immunity to viruses: learning from successful human vaccines. Immunol Rev 255:243-255

Reefhuis J, Gilboa SM, Johansson MA, Valencia D, Simeone RM, Hills SL, Polen K, Jamieson DJ, Petersen LR, Honein MA (2016) Projecting month of birth for at-risk infants after Zika virus disease outbreaks. Emerg Infect Dis 22:828-832

Reusken C, Pas S, GeurtsvanKessel C, Mogling R, van Kampen J, Langerak T, Koopmans M, van der Eijk A, van Gorp E (2016). Longitudinal follow-up of Zika virus RNA in semen of a traveller returning from Barbados to the Netherlands with Zika virus disease, March 2016. Euro surveillance: bulletin Europeen sur les maladies transmissibles $=$ European communicable disease bulletin 21 .

Richard AS, Zhang A, Park SJ, Farzan M, Zong M, Choe H (2015) Virion-associated phosphatidylethanolamine promotes TIM1mediated infection by Ebola, dengue, and West Nile viruses. Proc Natl Acad Sci U S A 112:14682-14687

Rinaldi S, Willison HJ (2008) Ganglioside antibodies and neuropathies. Curr Opin Neurol 21:540-546

Roberts DJ, Frosch MP (2016) Zika and histopathology in first trimester infections. Lancet 388:847-849

Rodenhuis-Zybert IA, Wilschut J, Smit JM (2010) Dengue virus life cycle: viral and host factors modulating infectivity. Cellular and molecular life sciences: CMLS 67:2773-2786

Rossi SL, Tesh RB, Azar SR, Muruato AE, Hanley KA, Auguste AJ, Langsjoen RM, Paessler S, Vasilakis N, Weaver SC (2016) Characterization of a novel murine model to study Zika virus. AmJTrop Med Hyg 94:1362-1369

Roze B, Najioullah F, Ferge JL, Apetse K, Brouste Y, Cesaire R, Fagour C, Fagour L, Hochedez P, Jeannin S, Joux J, Mehdaoui H, Valentino R, Signate A, Cabie A (2016). Zika virus detection in urine from patients with Guillain-Barre syndrome on Martinique, January 2016. Euro surveillance: bulletin Europeen sur les maladies transmissibles $=$ European communicable disease bulletin 21 .

Sapparapu G, Fernandez E, Kose N, Cao B, Fox JM, Bombardi RG, Zhao H, Nelson CA, Bryan AL, Barnes T, Davidson E, Mysorekar IU, Fremont DH, Doranz BJ, Diamond MS, Crowe JE (2016). Neutralizing human antibodies prevent Zika virus replication and fetal disease in mice. Nature.

Sarno M, Sacramento GA, Khouri R, do Rosario MS, Costa F, Archanjo G, Santos LA, Nery N Jr, Vasilakis N, Ko AI, de Almeida AR (2016) Zika virus infection and stillbirths: a case of hydrops fetalis, hydranencephaly and fetal demise. PLoS Negl Trop Dis 10: $\mathrm{e} 0004517$
Schuler-Faccini L, Ribeiro EM, Feitosa IM, Horovitz DD, Cavalcanti DP, Pessoa A, Doriqui MJ, Neri JI, Neto JM, Wanderley HY, Cernach M, El-Husny AS, Pone MV, Serao CL, Sanseverino MT (2016) Possible association between Zika virus infection and microcepha1y-Brazil, 2015. MMWR Morb Mortal Wkly Rep 65:59-62

Screaton G, Mongkolsapaya J, Yacoub S, Roberts C (2015) New insights into the immunopathology and control of dengue virus infection. Nat Rev Immunol 15:745-759

Sellers RS, Clifford CB, Treuting PM, Brayton C (2012) Immunological variation between inbred laboratory mouse strains: points to consider in phenotyping genetically immunomodified mice. Vet Pathol 49:32-43

Sharp TM, Munoz-Jordan J, Perez-Padilla J, Bello-Pagan MI, Rivera A, Pastula DM, Salinas JL, Martinez Mendez JH, Mendez M, Powers AM, Waterman S, Rivera-Garcia B (2016). Zika virus infection associated with severe thrombocytopenia. Clinical infectious diseases: an official publication of the Infectious Diseases Society of America.

Silva ML, Martins MA, Espirito-Santo LR, Campi-Azevedo AC, Silveira-Lemos D, Ribeiro JG, Homma A, Kroon EG, TeixeiraCarvalho A, Eloi-Santos SM, Martins-Filho OA (2011) Characterization of main cytokine sources from the innate and adaptive immune responses following primary 17DD yellow fever vaccination in adults. Vaccine 29:583-592

Singh VB, Singh MV, Gorantla S, Poluektova LY, Maggirwar SB (2016) Smoothened agonist reduces human immunodeficiency virus type1-induced blood-brain barrier breakdown in humanized mice. Sci Rep 6:26876

Soares de Souza A, Moraes Dias C, Braga FD, Terzian AC, Estofolete CF, Oliani AH, Oliveira GH, Brandao de Mattos CC, de Mattos LC, Nogueira ML, Vaz-Oliani DC (2016). Fetal infection by Zika virus in the third trimester: report of 2 cases. Clin Infect Dis.

Spalding KL, Bhardwaj RD, Buchholz BA, Druid H, Frisen J (2005) Retrospective birth dating of cells in humans. Cell 122:133-143

Srichaikul T, Nimmannitya S, Sripaisarn T, Kamolsilpa M, Pulgate C (1989) Platelet function during the acute phase of dengue hemorrhagic fever. The Southeast Asian journal of tropical medicine and public health 20:19-25

Stettler K, Beltramello M, Espinosa DA, Graham V, Cassotta A, Bianchi S, Vanzetta F, Minola A, Jaconi S, Mele F, Foglierini M, Pedotti M, Simonelli L, Dowall S, Atkinson B, Percivalle E, Simmons CP, Varani L, Blum J, Baldanti F, Cameroni E, Hewson R, Harris E, Lanzavecchia A, Sallusto F, Corti D (2016). Specificity, crossreactivity and function of antibodies elicited by Zika virus infection. Science.

Strafela P, Vizjak A, Mraz J, Mlakar J, Pizem J, Tul N, Zupanc TA, Popovic M (2016). Zika virus-associated micrencephaly: a thorough description of neuropathologic findings in the fetal central nervous system. Arch Pathol Lab Med.

Swanstrom JA, Plante JA, Plante KS, Young EF, McGowan E, Gallichotte EN, Widman DG, Heise MT, de Silva AM, Baric RS (2016). Dengue virus envelope dimer epitope monoclonal antibodies isolated from dengue patients are protective against Zika virus. mBio 7.

Tabata T, Petitt M, Puerta-Guardo H, Michlmayr D, Wang C, FangHoover J, Harris E, Pereira L (2016). Zika virus targets different primary human placental cells, suggesting two routes for vertical transmission. Cell host \& microbe.

Tang H, Hammack C, Ogden SC, Wen Z, Qian X, Li Y, Yao B, Shin J, Zhang F, Lee EM, Christian KM, Didier RA, Jin P, Song H, Ming GL (2016) Zika virus infects human cortical neural progenitors and attenuates their growth. Cell Stem Cell 18:587-590

Turmel JM, Abgueguen P, Hubert B, Vandamme YM, Maquart M, Le Guillou-Guillemette H, Leparc-Goffart I (2016) Late sexual transmission of Zika virus related to persistence in the semen. Lancet $387: 2501$ 
van der Eijk AA, van Genderen PJ, Verdijk RM, Reusken CB, Mogling R, van Kampen JJ, Widagdo W, Aron GI, GeurtsvanKessel CH, Pas SD, Raj VS, Haagmans BL, Koopmans MP (2016) Miscarriage associated with Zika virus infection. N Engl J Med 375:1002-1004

Valentine G, Marquez L, Pammi M (2016). Zika virus-associated microcephaly and eye lesions in the newborn. Journal of the Pediatric Infectious Diseases Society.

Ventura CV, Maia M, Dias N, Ventura LO, Belfort R Jr (2016) Zika: neurological and ocular findings in infant without microcephaly. Lancet 387:2502

Vinhaes ES, Santos LA, Dias L, Andrade NA, Bezerra VH, de Carvalho AT, de Moraes L, Henriques DF, Azar SR, Vasilakis N, Ko AI, Andrade BB, Siqueira IC, Khouri R, Boaventura VS (2016). Transient Hearing Loss in Adults Associated with Zika Virus Infection. Clin Infect Dis. doi:10.1093/cid/ciw770

Weaver SC, Costa F, Garcia-Blanco MA, Ko AI, Ribeiro GS, Saade G, Shi PY, Vasilakis N (2016) Zika virus: history, emergence, biology, and prospects for control. Antivir Res 130:69-80

White MK, Wollebo HS, Beckham JD, Tyler KL, Khalili K (2016). Zika virus: an emergent neuropathological agent. Annals of neurology.
WHO (2016a). Current Zika product pipeline.

WHO (2016b) Dengue vaccine: WHO position paper. World Health Organization:349-364

Willison HJ (2007) Gangliosides as targets for autoimmune injury to the nervous system. J Neurochem 103(Suppl 1):143-149

Wiwanitkit V (2016). Zika virus infection spread through saliva. Brazilian oral research 30 .

$\mathrm{Xu}$ M, Lee EM, Wen Z, Cheng Y, Huang WK, Qian X, Tcw J, Kouznetsova J, Ogden SC, Hammack C, Jacob F, Nguyen HN, Itkin M, Hanna C, Shinn P, Allen C, Michael SG, Simeonov A, Huang W, Christian KM, Goate A, Brennand KJ, Huang R, Xia M, Ming GL, Zheng W, Song H, Tang H (2016) Identification of small-molecule inhibitors of Zika virus infection and induced neural cell death via a drug repurposing screen. Nat Med 22:1101-1107

Yamaguchi Y, Miura M (2015) Programmed cell death in neurodevelopment. Dev Cell 32:478-490

Zhao H, Fernandez E, Dowd KA, Speer SD, Platt DJ, Gorman MJ, Govero J, Nelson CA, Pierson TC, Diamond MS, Fremont DH (2016). Structural basis of Zika virus-specific antibody protection. Cell. 